\title{
Susanne Friede
}

\section{When History Does Not Fit into Drama: Some Thoughts on the Absence of King Arthur in Early Modern Plays}

King Arthur - and perhaps his realm as a whole - is one of the most important, if not the most important character, or topic, in medieval narrative literature. Today, his literary prominence is as relevant as ever. Next to many modern literary (re)interpretations set in King Arthur's reign (for example, the works of T. H. White and Marion Zimmer Bradley), there are more and more cinematic adaptations that show the life and the death of Arthur (for example, King Arthur, 2004, directed by Antoine Fuqua; King Arthur: Legend of the Sword, 2017, directed by Guy Ritchie). Given the medieval literary prominence of the figure of King Arthur, the following question arises: why is there no historical play about Arthur in the early modern period? It is, to be sure, difficult, if not impossible, to consult the entire output of the early modern stage. However, there is certainly no prominent play that includes the (pseudo)historical King Arthur.

This absence of a historical early modern Arthurian play must not be taken for granted, as the enormous dissemination of Thomas Malory's Morte d'Arthur (first published in 1485) proves. There are, in fact, also some German carnival plays (Fastnachtsspiele) that are randomly based on the quasi-mythological background of the Arthurian world. At least three Fastnachtsspiele from different cultural backgrounds refer to Arthurian material. Two of them, Das vasnachtspil mit der kroon and Der Luneten Mantel (whose manuscripts date from 1455 to 1458) are from Nuremberg. However, these two plays, which refer solely to the 'frame' of the Arthurian world and its heroes, do not introduce King Arthur as a character. They only use Arthurian 'narrative elements' to stage a 'test of chastity,' or conjugal fidelity. A third, more complex example, Ain hupsches Vasnacht Spill von Künig Artus, comes from Swabia (the manuscripts dating from 1486-1520). ${ }^{1}$

\footnotetext{
1 I warmly thank Thomas Habel for his gracious hints and explanations. - The plays can be found in Adalbert von Keller's anthology Fastnachtsspiele aus dem fünfzehnten Jahrhundert. 4 vols. Stuttgart: Bibliothek des Litterarischen Vereins, 1853-1858. [Reprint: Darmstadt: Wissenschaftliche Buchgesellschaft, 1965-1966]. Das vasnachtspil mit der kron appears as no. 80, Der Luneten Mantel is no. 81, and Ain hupsches Vasnacht Spill von Künig Artus is no. 127. Cf. also Kurt Ruh, editor. Die deutsche Literatur des Mittelalters: Verfasserlexikon, vol. 5. Berlin: de Gruyter, 1985. All three plays are mentioned there: Das vasnachtspil mit der kron (p. 384),
} 
Still, why is there no historical play about King Arthur in the early modern period? One explanation of remarkable importance is that the history of Arthur cannot provide a heroic model. First, it is necessary to underline the fact that the Middle Ages and the early modern period knew considerably more religious (i.e. biblical or salvific) plays than secular historical plays. While the notion of 'secular theater' does not refer to a homogeneous group of texts, the distinction between religious and profane theater is rather sharp. ${ }^{2}$ For example, a manuscript from Wolfenbüttel edited by Alan E. Knight ${ }^{3}$ gives a clear idea of this difference and underscores preferences of Renaissance playwrights with regard to content. It contains a collection of mystères performed during the processions at Lille. From these 74 mystères, almost all, i. e. 69, are religious plays, and only 5 are historical mystères treating episodes from Roman history. 'Historical' playwrights could select their topics from biblical history, saints' lives, or, à la limite, secular history, as is the case in the mystères of Lille. However, they had to include a moral, or at least stage a hero with outstanding values and comportment, ${ }^{4}$ who would ideally serve as a typological example for biblical protagonists and Christian virtues. A play about King Arthur could not have belonged to Roman history, and it would have been difficult to represent Arthur's life as a praiseworthy example of biblical, or as a part of salvific history. ${ }^{5}$

In her article in this volume, Gaia Gubbini discusses different factors that caused the decline of King Arthur and his reign as told in La Mort le Roi Artu, the last part of the Prose Lancelot-Grail Cycle, a complex cycle generated in growing stages between 1210 and 1235/40. In La Mort le Roi Artu, the narrator provides a lot of overt explanations to rationalize the decline of the Arthurian empire. Explicit comments on Lancelot's, Guinevere's, and indirectly also on Arthur's behavior stress both their subjective guilt (also through the Christian term pechié) and their objective guilt (without any sense of misbehavior on the part of the heroes). The latter, the objective guilt, is, for example, evoked by the incestuous relationship

Der Luneten Mantel (p. 1221) and Ain hupsches Vasnacht Spill von Künig Artus, i.e. König Artus' Horn (pp. 70-72).

2 Cf. Alan E. Knight. Aspects of Genre in Late Medieval French Drama. Manchester: Manchester University Press, 1983, esp. pp. 17-40, as well as Charles Mazouer. Le théâtre français du Moyen Âge. Paris: Sedes, 1998, chapters I and IV.

3 Alan E. Knight, editor. Les mystères de la procession de Lille. 2 vols. Geneva: Droz, 2001/2003.

4 See the excellent article by Konrad Schoell. "Le théâtre historique au XVe siècle." Divers toyes mengled: Essays on Medieval and Renaissance Culture in Honour of André Lascombes, edited by Michel Bitot. Tours: Université François Rabelais, 1996, pp. 189-196.

5 In a purely technical sense, it would have been difficult to give (as is regularly done in the mystères of Lyon) a moral of the play in the epilogue or to mention its precise historical sources in an argumentum at the beginning. 
between Arthur and Morgane that is insinuated in the text. It is true that the very first vernacular text mentioning King Arthur, Wace's chronicle (Roman de) Brut, depicts him as a strong and combative, successful, and very courageous hero (which is why the Plantagenets could refer to this 'historical' figure for the legitimization of their claim to power). However, in other texts of the twelfth century that belong to different genres, he is described as a rather weak and passive king whose significance is not as great as that of the other knights of the Round Table. This is, for instance, true of the lai Lanval and Chrétien's courtly romances, including Lancelot, ou le Chevalier de la charrette and Perceval, ou le Conte del Graal. In the Prose Lancelot-Grail Cycle, and notably in La Mort le Roi Artu, King Arthur's position weakens even further, and finally he is lethally wounded by his own nephew. In this way, medieval French texts about King Arthur provide an impressive example of how reworking existing figures can be provocative in literature.

In fact, from the beginning of the thirteenth century at the latest, the history of Arthur was no longer able to provide a heroic model, as had been the case, albeit for a very short period, in the middle of the twelfth century (Wace's Roman de Brut). It therefore does not necessarily matter whether a potential early modern play about King Arthur would have been conceptualized and perceived as a literary or as a historiographical drama.

To point out further probable reasons for the absence of a historical play about King Arthur in the early modern period, it will be helpful to look at the - in some regards contrary - example of Alexander the Great. In his study of theological and humanistic erudition in the early French theater, Tobias Leuker analyzes the mystère called Les Épitaphes d'Hector et d'Achille by George Chastelain, which was staged in Nevers in $1454 .{ }^{6}$ He examines and outlines the novel perspective that this play aims to offer on ancient history. The main character, Alexander the Great, reads and judges the epitaphs of the two great heroes of the Trojan War, Hector and Achilles. To redeem Hector, whose epitaph declares that he has been perfidiously killed by Achilles, Alexander calls Achilles up from the depths of the netherworld and arranges a ‘confession conversation' between Achilles and Hector.

Apart from the single flaw that he is not a Christian, Alexander (like Hector) functions as a nearly perfect example of ideal behavior as prescribed by the idea of nobility in most ancient and medieval romances, which partly appear in the shape of a 'mirror of princes.' That is why Alexander and Hector are both held in the limbus (the siège des Preux) in Chastelain's play. ${ }^{7}$

6 Tobias Leuker. Vom Adamsspiel bis Jodelle: Theologische und humanistische Gelehrsamkeit im frühen französischen Theater. Köln: Böhlau, 2016, pp. 109-130.

7 Cf. ibid., p. 130. 
Although Alexander was always perceived as a historical figure in medieval literature (which was not always and not necessarily the case for Arthur), ${ }^{8}$ both heroes experience a literarily stylized tragic ending. While Arthur is lethally wounded by his nephew Mordred, Alexander is poisoned by two of his servants, whom he has overly trusted. Chastelain's play further examines Hector's death and its influence on the hero's posthumous fate. In this way, it shows how important it is for a literary character based on a mythological or historical hero to experience an 'appropriate' death.

Given this context, Alexander, as opposed to Arthur, represents the ideal kind of hero that fits into a historical (and necessarily moral) early modern play. Even the moral of his death and destiny emphasized in medieval romances: not to trust the non-noble, could indirectly refer to his remarkable noble qualities. On the contrary, Arthur's death, caused by a treacherous relative, only underlines the deep corruption of his whole kin.

Finally, the question regarding the absence of King Arthur from early modern plays is also a matter of genre. During the thirteenth century at the latest, the matière de Bretagne established a considerable tie to the romance genre, which is especially evident in the Prose Lancelot-Grail Cycle. To show the possible, the credible, and to develop fully its own narrative power (to be $\varphi \iota \lambda о \sigma o \varphi \omega ́ \tau \varepsilon \rho o v$ in a figurative sense), the Arthurian material clearly required a narrator's voice rather than a mise en scène. However, only the long narrative genre allows the establishment of a link between the topic of subjective and objective guilt of the heroes and the mythological level of explanation culminating in the motif of the Wheel of Fortune. The aspects underlying the complex portrait of King Arthur and his world required explanations and comments that could only be provided by a narrator. These aspects included the highly contradictory display of King Arthur as a hero and as a victim, of his realm as an ideal and at the same time disrupted world, as well as of the manifold forms of guilt of the king, the queen, and the Knights of the Round Table. This is perhaps one of the most important reasons why it was difficult to put the Arthurian heroes and Arthur himself on stage (or in a play) without a narrator's commenting voice. Until today, long narrative genres (including film, which is 'more narrative' than the stage play) seem to have been the only means to explain the Arthurian 'universe.'

8 See, for example, the following three studies: Martin Gosmann. La légende d'Alexandre le Grand dans la littérature française du $12^{\mathrm{e}}$ siècle: Une réécriture permanente. Amsterdam: Rodopi, 1997; Catherine Gaullier-Bougassas. Les Romans d'Alexandre: Aux frontières de l'épique et du romanesque. Paris: Champion, 1998; Susanne Friede. Die Wahrnehmung des Wunderbaren: Der Roman d'Alexandre im Kontext der französischen Literatur des 12. Jahrhunderts. Tübingen: Niemeyer, 2003. 